\title{
The Influence of Women in the New Testament on Christian Women in Pentecostal Churches towards Evangelism in Kano State
}

\author{
Okegbile, Binta
}

\begin{abstract}
This study is on the influence of women in the New Testament on Christian women in Pentecostal churches towards evangelism in Kano State. This is a survey research which covered nine Pentecostal churches in Kano State. There were (110) registered Pentecostal churches in Kano State and (52,923) Christian women. However, (500) women were used as sample. The instrument used for this study was questionnaire. Two hypotheses were formulated and data from the tested hypotheses were analyzed using statistical package for social sciences (SPSS). Analysis were based on (452) respondents who completed and returned their questionnaire. The results of the study were presented. Hypotheses I, and II were all rejected. The major findings of this study were that age of Christian women in Pentecostal churches significantly influenced their participation in evangelism. Marital status of Christian women in Pentecostal churches significantly influenced their participation in evangelism.
\end{abstract}

Index Terms - Christian Women in Pentecostal Churches, Evangelism, Kano State.

\section{INTRODUCTION}

Evangelism is the activity by which the church proclaims the Gospel of Jesus Christ. To evangelize is to preach the gospel. To share the good news of Christ, in order to convince someone to join or accept it. In the New Testament, it was observed that some of the women who participated in evangelism were of different ages and marital status. Those married include: Peter's mother in-law (Luke 4:38 -39), Mary the mother of James and Josses (Mat. 27: 56), Salome, Mother of James and John (Mat. 20:20). Joanna the wife of Chuza (Luke 8:3) and Mary, mother of John Mark (Luke 24-10; John 19-25), Eunice (2 Timothy 5), Priscilla (Acts 18). Women like Dorcas (Acts 9:36-42), Mary, Lazarus' sister (John 11), Mary Magdalene (Luke 7:38-39), Phoebe (Romans 16:1), Philip's daughters (Act 21:9) were not married. The marital status of other women were not clearly defined, for instance, Lydia (Acts 16), and Martha (Luke 10:40). This presupposes that women of various marital status in the New Testament participated in evangelism.

The compelling basis for women's role in evangelism perhaps is an understanding of the freedom of God's Spirit to bestow gifts upon women and men (Joel: 2:28). For women to be willing to take part in evangelism despite the repressions

Okegbile, Binta, Federal College of Education (Technical) Bichi, P.M.B 3473 Kano State, Nigeria. occasioned by culture, denominational beliefs and other factors, there must have been models or motivational factors influencing them.

\section{RESEARCH QUESTIONS}

Research questions proposed for this study include:

i. How does the age of Christian women in Pentecostal churches in Kano State influence their participation in evangelism?

ii. How does the marital status of Christian women in Pentecostal churches in Kano State influence their participation in evangelism?

\section{HYPOTHESES}

The following hypotheses were postulated in the course of this study.

i. The age of Christian women in Pentecostal churches does not significantly influence their participation in evangelism.

ii. Marital status of Christian women in Pentecostal churches does not significantly influence their participation in evangelism.

\section{METHODOLOGY}

A survey research design was used for this study. The instruments employed to carry out the survey was the questionnaire. The population for this study consists of all Christian women in Pentecostal churches in Kano State, Nigeria, comprising of (110) registered Pentecostal churches. The total number of women in all of the registered Pentecostal churches were $(52,923)$ Christian women according to the records given by the Secretary, Pentecostal Fellowship of Nigeria (PFN), Kano State Branch.

\section{SAMPLE AND SAMPLING PROCEDURE}

The sample was drawn from the population of all Christian women in Pentecostal churches in Kano State in order to get a fair representation of all the churches and women. Cluster random sampling was used to get representative from each population cluster in proportion to actual size of the group. The number of Christian women required and used for the study were (500). Therefore, the clusters were first identified among which are: Fagge, Nassarawa, Kumbotso, Sumaila, Tiga and Bichi Local Government. To ease sampling procedure, 
churches were classified in terms of congregation as large (above 500 members), average (between 200 and 500 members) or small (below 200 members). Nine churches were selected, three each from large, average and low congregations. The churches were selected in proportion with the population, seven churches from Fagge and one each from Nassarawa and Bichi Local Government. From these churches, 500 Christian women were randomly selected and used for the study.

\section{INSTRUMENTATION}

To collect data for this study, a questionnaire titled: Women in New Testament and Women in Pentecostal (WINTAWIP) was disributed. Items requests information of respondents such as, age, occupation, qualifications, marital status and name of church. Data analysis was done based on the hypotheses formulated. Descriptive data analyses were presented. Relationship between the variables were also measured, the first and second hypotheses (Ho1) and (Ho2) involved the use of frequency and percentage.

\section{TEST OF HYPOTHESES}

Hypothesis one:

The age of Christian women in Pentecostal churches in Kano State does not significantly influence their participation in evangelism

One way analysis of variance (ANOVA) was used to test the influence of age on Christian women participation in evangelism.

\begin{tabular}{|c|c|c|c|c|c|c|}
\hline Source & $\begin{array}{l}\text { Sum of } \\
\text { Square }\end{array}$ & $\begin{array}{c}\text { df } \\
\text { square }\end{array}$ & Mean & Fob & $\mathbf{P}$ & Fcritical \\
\hline$\overline{\text { Between }}$ & 2550.12 & 4 & 637.53 & 5.47 & 0.05 & 2.39 \\
\hline Within & 52118.38 & & 447 & 116.60 & & \\
\hline
\end{tabular}

From the table above $(\mathrm{F}, 4,447)=2.39 ; \mathrm{P}<.05$. This means that $\mathrm{F}$ observed is greater than $\mathrm{F}$ critical, hence at $5 \%$ level of significance, the null hypothesis is rejected. This implies that the ages of women determine the level of participation in evangelism. Since there is a significant influence of age, a post hoc analysis of mean is therefore required to determine which of the pair of means influence the significant participation. A presentation of the mean is therefore required.

Summary of mean of Christian women of different age groups

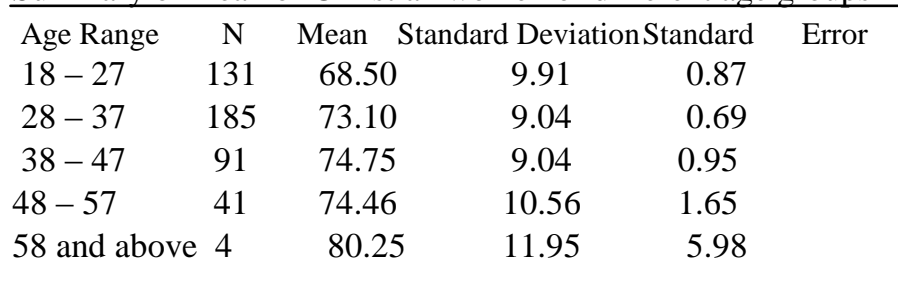

This shows the summary table of mean of Christian women of different age groups with age group 58 and above having the highest mean and 18-27 age group having the lowest. Applying the Scheffe's post hoc test, the table below gives the summary of
F ratio.

Hypothesis two:

Marital status of Christian women in Pentecostal churches in Kano State does not influence their participation in evangelism.

Scores of the respondents on the influence of marital status was carried out using one way analysis of variance (ANOVA).The use of the one way analysis of variance is due to the multiple levels of the independent variable (Marital status of the respondents) which require a multiple comparison of the marital status of the respondents. The analysis of variance model is presented in the table below.

ANOVA on influence of marital status on the respondents

\begin{tabular}{llccccc}
\hline Source & $\begin{array}{l}\text { Sum of } \\
\text { Square }\end{array}$ & $\begin{array}{c}\text { df } \\
\text { square }\end{array}$ & Mean & Fob & P & Fcritical \\
\hline Between & 2149.85 & 2 & 1074.93 & 9.17 & 0.00 & 3.02 \\
Within & 52637.98449 & & 17.23 & & & \\
\hline Total & $\mathbf{5 4 7 8 7 . 8 3}$ & & & & & \\
\hline
\end{tabular}

The result on the table shows that $(\mathrm{F}(2,449)=3.02 ; \mathrm{P}<.05)$. Since $\mathrm{F}$ calculated is greater than Fcritical at $5 \%$ level of significance, the Null hypothesis is rejected. This implies that marital status of Christian women in Pentecostal churches significantly influenced their participation in evangelism. In the effect that there is significance, it would be necessary to identify which of the status have the significant difference. To this effect, a comprehensive presentation of descriptive measures is required as in the table below.

Mean score of the participation of Christian women in Pentecostal churches in evangelism by marital status.

\begin{tabular}{lcccc}
\hline Status & N & Mean & Standard Deviation & Standard Error \\
\hline Married & 289 & 73.75 & 9.22 & 0.54 \\
Unmarried & 150 & 69.03 & 10.61 & 0.87 \\
Widowed & 13 & 77.38 & 7.29 & 2.02 \\
\hline
\end{tabular}

The mean scores of the participation of Christian women in Pentecostal churches towards evangelism by marital status indicate some differences. The widowed having the highest mean scores, followed by the married and then the unmarried. From the table showing the mean ratings of participation of married, unmarried and widowed women in Pentecostal churches, a Scheffe's post hoc multiple comparisons of mean was done in order to know where the significance really existed and which pairs produced the difference. The Scheffe's post hoc test revealed that 63.84 is greater than 3.02. It was concluded that there is a significant difference between mean rating of married and unmarried women; widowed and unmarried. It can therefore be concluded that there is a significant difference between mean rating of married and unmarried women. Similarly, there are significant differences between married and widowed; widowed and unmarried. This test summarily confirmed that all pairs of means compared contribute to the significant difference of marital status on Christian women's participation in evangelism. Moreover, it can be concluded that, the widowed participate better than the married, while the 
unmarried participate least in the group. This may not be at variance with what took place in New Testament days.

\section{DISCUSSIONS}

From the data analysis, it was discovered that age influences the participation of Christian women in Pentecostal churches in evangelism. Older women participate better than younger women. Again, the study revealed that marital status of Christian women in Pentecostal churches significantly influenced their participation in evangelism. The widows participate more than the married while the married participate more than the unmarried in evangelism.

\section{CONCLUSION}

Based on the findings, the following conclusions were made.

1. Christian women in Pentecostal churches appreciate women in the New Testament who participated in one form of evangelism or the other, but greater number of them are restricted to just a few aspects of evangelism.

2. On the aspects of marital responsibilities which to some extent may serve as hindrance to Christian women involvement in evangelism, these women need to set their priorities right and avoid procrastination so that they will be able to fulfill all that is expected of them and be able to influence their world like women in the New Testament.

\section{REFERENCES}

[1] Akanni, S. (2007). God Uses Women. More than Rubies. 7(1), 3.

[2] Brown, A. (1991). Apology to Women: Christian Images of Female Sex. Leicester Inter-Varsity Press.

[3] Deen, E. (1955). All of the women of the Bible. New York: Harper and Brothers.

[4] Edukugho, J. D. (2005, May 22). The Church has given Evangelism the Back Seat. The Guardian Pp. 30 and 35.

[5] Elue, M. O. (2006). The Challenge of Pentecostalism in Nigeria Church. In A. G. Nnamani (Ed.). The New Religious Movements: Pentecostalism in perspective. Benin City: Ava Publishers.

[6] Hagin, K. E. (2004). The Woman Question - Benin City. Faith Library Publications.

[7] Holy Bible (2000). New International Version. United State of America: Zondervan Publishers.

[8] Munroe, M. (2001). Understanding the Purpose and Power of Women. New Kensington. Whitaker House.

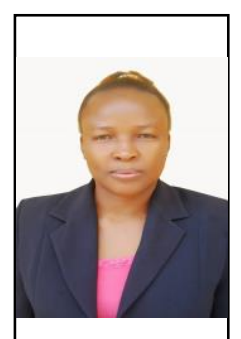

Dr. (Mrs) Binta Okegbile was born in Katcha Niger State, Nigeria on the 5th of May, 1969. She obtained her Nigeria Certificate in Education in 1993, her first degree in 2005, Masters Degree in 2010 and her Ph.D in the year 2016 all from Ahmadu Bello University, Zaria, Nigeria. Her area of specialization is Christian Religious Studies.

She lectures in Federal College of Education (Technical) Bichi, Kano State, Nigeria. She is presently a Senior Lecturer and Head of Department, Primary Education. She has published four books among them is the Essentials of Christian Religious Studies and Moral Education published at the Ahmadu Bello University Press, Zaria. She is the founder and president of Kingdom Revival Mission International, a Ministry presently based in Kano State, Nigeria. 